\title{
The problem of constitutional legitimation: what the debate on electoral quotas tells us about the legitimacy of decision-making rules in constitutional choice
}

\author{
Aris Trantidis*
}

\begin{abstract}
Proponents of electoral quotas have a 'dependent interpretation' of democracy, i.e. they have formed an opinion on which decision-making rules are fair on the basis of their prior approval of the outcomes these rules are likely to generate. The article argues that this position causes an irresolvable problem for constitutional processes that seek to legitimately enact institutional change. While constitutional revision governed by formal equality allows the introduction of electoral quotas, this avenue is normatively untenable for proponents of affirmative action if they are consistent with their claim that formal equality reproduces biases and power asymmetries at all levels of decision-making. Their critique raises a fundamental challenge to the constitutional revision rule itself as equally unfair. Without consensus on the decision-making process by which new postconstitutional rules can be legitimately enacted, procedural fairness becomes an issue impossible to resolve at the stage of constitutional choice. This problem of legitimation affects all instances of constitutional choice in which there are opposing views not only about the desired outcome of the process but also about the decision-making rules that govern constitutional choice.
\end{abstract}

This is an earlier version of the article that appears in Constitutional Political Economy, January 2017. Please cite as follows:

Trantidis, Aris (2017). Constitutional Political Economy, doi:10.1007/s10602-016-9233-7

\section{Introduction}

The case for electoral quotas raises a fundamental challenge to formal equality as the decision-making principle and exposes a fundamental problem of legitimacy affecting constitutional choice. By the term legitimacy I refer to the inter-subjective perceptions that decision-making rules are 'fair' in the sense that all competing parties will regard them as impartial — not necessarily optimal — towards competing views held by different groups. Proponents of affirmative action criticize formal equality for being an unfair rule because it tends to reproduce the same set of biases and power asymmetries that account for the under-representation of certain groups in other spheres of social activity. They advocate affirmative action in the sphere of politics - in the form of electoral quotas or the short listing of candidates - as a means to achieving some degree of 'equality of result'. Such a change in the decision-making rules will mark a departure from formal equality, seen as a 'one person, one vote' rule and will enact preferential treatment in favor of a demographic group. 
A constitutional process that conforms to formal equality can legitimately introduce electoral quotas. This approach interprets any proposal for constitutional change as a set of arguments seeking to gain support following a rule of constitutional choice in which all participants have one vote; this rule reflects the equal standing of the citizens who elect them or directly participate in the constitutional process (one person, one vote). However, this constitutional pathway is highly problematic for proponents of affirmative action. Arguments in favor of affirmative action endorse 'equality of result' or a version of 'equality of opportunity' as the fair principle that must govern both outcome and process. They put forward a 'dependent interpretation' of fair process: an opinion on procedural fairness that has been formed on the basis of prior approval of the outcomes this process is likely to generate. In dependent interpretations of legitimacy, such as the one held by affirmative action proponents, perceptions of fairness regarding procedural rules are connected to perceptions of fairness regarding the outcome of a decision-making process. Support for a set of decision-making rules is driven by perceptions of fairness concerning their possible output.

Hence, views on fair process and views on fair outputs are interdependent and, subsequently, intertwined into a single argument. These co-dependent perceptions of fairness are antithetical to normative individualism and require a departure from its corresponding decision-making rule: formal equality. By that very fact, it is untenable for proponents of affirmative action to submit their proposals for public approval to a decisionmaking process that conforms to procedural rules which they regard as inherently flawed and they seek to replace. If they welcome any changes in the status quo that have been enacted through a decision-making process they consider as intrinsically flawed, they will be inconsistent with their own critique. The enactment of new rules through a flawed process will be ipso facto stripped of procedural legitimacy. Moreover, insofar as proponents of affirmative action hold the idea that formal equality reproduces an objectionable state of affairs, getting their desired change in the post-constitutional rules through processes conforming to formal equality-particularly by unanimity or supermajority-will implicitly weaken the core of their substantial arguments. Alternatively, if they don't get their desired change, they can fall back on their 'dependent interpretation' of the decision-making system and raise an objection to this outcome on the basis of a critique that targets the process itself. This paradoxical situation stems from the fact that proponents of affirmative action have made a choice regarding which decisionmaking rule is fair on the basis of prior consideration of the kind of outcomes it is likely to produce.

The contrast between the two interpretations of proposals for affirmative action reveals a general problem affecting constitutional legitimation. On the one hand, a constitutionalcontractarian approach that adheres to the principle of formal equality can legitimately enact affirmative action and other outcome-dependent rules in the post-constitutional order that are deviations from the rule of formal equality. On the other hand, the interpretation of such proposals as substantive arguments that directly confer legitimacy to the procedural rules themselves complicates the need to have these proposals legitimized through constitutional choice by obfuscating the boundaries between legitimate process and fair outcome. The presence of the latter type of arguments generates a problem of constitutional legitimation: a normative impasse emerges when proponents of constitutional change defend their proposals on grounds that also involve a critique of the process by which they are supposed to be enacted. 
The paper develops this argument as follows. The next section explains why the case for affirmative action is a contentious claim with no superior status over other visions of procedural fairness and must, therefore, undergo a process of approval like any other contestable claim. I show that this pathway can be accommodated by a revision process that adheres to formal equality, including, theoretically, the stricter requirements of the contractarian-constitutional tradition of James Buchanan where unanimity serves as the rule governing constitutional choice. I then move to discuss the fundamental objection which the case for electoral quotas poses to formal equality and its underlying principle, normative individualism and why this objection blocks this pathway. In the final part, I discuss the implications of this position: why it is problematic to merge a policy agenda for social change with a critique of the decision-making process itself.

\section{Affirmative action as a contentious claim and the constitutional process}

Proponents of affirmative action want to modify the rules governing political decisionmaking processes such as general elections or other selection procedures, by introducing quotas and other quantitative measures that will increase the representation of socially disadvantaged groups in decision-making posts. Their proposals are often backed by arguments invoking a vision of fairness that links the decision-making process with its most likely outcomes. This vision of 'equal opportunity' and 'equality of result' is to be achieved through affirmative action that also includes decision making processes and the election of representatives. Consider the case of women in politics. Affirmative action is recommended as a way to secure the proportional participation of women - and other under-represented groups - in several social, professional and political posts (Cf. Htun 2004; Meier 2000). These arguments build on a judgment over the fairness of the social outcome that the established rules tend to reproduce and the new rules will generate. Introducing electoral quotas or short lists of candidates is the suggested way to improve equality on a 'substantive' basis. By reserving a certain number or percentage of women as elected representatives or candidates, affirmative action is seen as a means to rectifying the political imbalance between men and women and securing the proportional presence of women in politics (Kymlicka 1993; Darcy et al. 1994; Lovenduski 1997; Dahlerup and Freidenvall 2005):

[...] the link between women's representation and democracy should be selfevident, since women account for over half the population of most societies: if the majority doesn't have full political rights, the society is not democratic (Inglehart, Norris and Welzel, 2002, p. 321)

Quite interestingly, these proposals require approval through a process of institutional change. Given the status quo, this process shall legitimately introduce affirmative action as a deviation from the established principle: formal equality described succinctly as 'one person, one vote'. Formal equality gives each candidate and each voter an equal standing in the electoral process regardless of their identity (Cf. Bacchi 2006; Guadagnini 1998; Russell 2000) and whatever the outcome of voting may be. This principle allows deliberation on a debate in which arguments in favor and against the proposed amendments will be discussed and decided upon. From the perspective of normative individualism there are key objections that have to be addressed: a) 'is it necessary, desirable or even feasible to apply the principle of equal substantive treatment to social and demographic groups?', 
or b) 'does affirmative action violate substantive equality on an individual level given the heterogeneity of circumstances within these groups?'

These questions refer to key criticisms of affirmative action. Thinking in terms of groups overlooks the reality of multiple and overlapping personal identities in a diverse social context (Kymlicka 1995, pp. 144-145) and cannot fully achieve the goal of substantive equality. To achieve full substantive equality would require the rectification of individual circumstances instead of indiscriminate group-level interventions. Given that an individual's life status is shaped by membership in various demographic and social groups (Maier and Klausen 2001; Weldon 2002, pp. 1156-1159; Ward et al., 2008), there are practical and insurmountable obstacles to achieving substantive equality or equal opportunity on individual level. The amount and nature of interventions necessary to tackle patterns of inequality across and inside demographic groups is intractable and therefore impossible for a political system to offer (Tebble 2002, pp. 266-272). Moreover, while we can empirically identify group-specific patterns of inequality or marginalization, we must equally consider diversity within these demographic groups. The application of affirmative action indiscriminately across all members of a group overlooks its internal heterogeneity in terms of individual circumstances.

This critique suggests that affirmative action grants additional privileges to certain members of a social or demographic group who are already advantaged due to other personal circumstances (Wilson 1987; Landau 1997; Sowell 2004). Introducing grouplevel interventions could reintroduce discrimination on an individual basis (reverse discrimination). Changing the social composition of elected posts or candidate lists to reserve a proportion for politically under-represented groups deprives individual candidates of equal treatment from political institutions, and may disadvantage certain candidates who are indiscriminately seen as members of the 'privileged group'.

The feminist literature has raised similar questions over the concept of group identity and the meaning of group-related disadvantage (Young 1990), patterns of sub-group domination (Young 2000, p. 150), the diversity of perspectives among group members (Gould 1996, p. 182; Williams 1998, p. 6), the presence of within-group inequalities and whether different groups and different patterns of under-representation require different remedies (Htun 2004). This critique rethinks group identity, oppression and marginalization beyond the concepts of a demographic aggregate or a voluntary association (Young 1990, pp. 43-44).

Given the spectrum of views, affirmative action can be seen as one contestable claim among others, which a political system can select or reject. A democratic system sets up the process by which public approval will make this policy selection legitimate. At that stage, legitimacy is granted to a set of policy proposals by a decision-making process which the political community must - at least widely — consider to be fundamentally fair. In that sense, the legitimacy of a policy depends on the perceived fairness of the process through which a decision-making body introduces it, and not the other way around.

It is through this process that several countries introduced measures of affirmative action for social groups, typically racial or ethnic minorities and women. When, on many 
occasions, electoral quotas clashed with constitutional principles such as formal equality, the constitutional provisions themselves were amended through the process stipulated by the established rules of constitutional revision. For instance, in France and Italy, the introduction of quotas through national legislation in 1982 and 1995 respectively was declared unconstitutional on the grounds of breaching the principle of equality between men and women (c.f. Guadagnini 1998; Russell 2000). Constitutional amendments were passed to overturn the previous rulings on unconstitutionality. This constitutional avenue has allowed democratic systems to pass a rule that has distributional consequences, which the standards of formal equality see as reverse discrimination.

In this regard, electoral quotas can be introduced as the new decision-making rule insofar as a legitimate constitutional process authorizes this change. Political constitutions typically place higher voting thresholds for constitutional amendment compared to ordinary collective decisions (Cf. Buchanan 1975/1999: 106). This pathway is compatible with the logically coherent version of constitutional theory that is solidly rooted in normative individualism: the contractual-constitutional tradition launched by James Buchanan and Gordon Tullock with the Calculus of Consent and developed by Buchanan and other authors in subsequent years (e.g. Buchanan and Congleton 1998). A constitutional path conforms to the principle of normative individualism, according to which 'separate individuals... are likely to have different aims and purposes for the results of collective action' (Buchanan and Tullock 1962, pp. 6, 14). There are two discrete stages of social interaction and decision-making: 'one which involves the selection of rules and one which involves action within these rules as selected' (Buchanan 1975/1999: 9). Both 'the desirability and legitimacy of constitutional arrangements' is to be assessed in terms of 'the preferences of, and the voluntary agreement among, the individuals who live under (or are affected by) the arrangements' (Vanberg 2004, p. 154). There is here a clear distinction between the contested fairness of specific policy outputs and the fairness of the process itself which opponents over a proposed policy must accept as legitimate.

The solution that this tradition offers accommodates claims for affirmative action, such as electoral quotas, insofar as these proposals are seen as modifications of the postconstitutional setting and are approved at the constitutional stage by unanimity: contracting agents may agree to establish a reformed post-constitutional setting which includes electoral quotas as part of the decision-making rules:

Finally, the basic contract must define the rules under which the collectivity must operate in making and in implementing decisions concerning the provision and financing of "public goods." This set of terms will specify in detail the operation and the limits of the productive state, the legislative aspect of collective organization... Within these defined limits, allowable departures from unanimity in reaching collective decision should be specified. (Buchanan 1975/1999: 69)

These operational departures from unanimity were, however, themselves conceptually derived from general, and presumably, unanimous agreement in constitutional contract, which specifies rules for reaching operational collective decisions in addition to defining individual behavioral limits (Buchanan 1975/1999: 105) 


\section{Affirmative action and the dependent interpretation of democracy}

Proponents of affirmative action can agree to follow a constitutional path that would modify the decision-making rules. Mansbridge, for instance, acknowledges that granting descriptive representation can be compatible with the nature of democratic process in cases in which 'constitutional designers and individual voters have reason to institute policies that promote descriptive representation, even when such implementation involves some losses in the implementation of other valued ideals' (Mansbridge 1999, pp. 628-629). The adoption of descriptive representation measures will increase 'de facto legitimacy within the disadvantaged group' (1999: 652) but will be accorded only if the claim for descriptive representation gains political ground: '...political parties, legislative committees and voters weigh the pros and cons of descriptive representation' (Mansbridge 1999, p. 629). Several arguments were framed to call for affirmative action without openly challenging formal equality as the decision making rule that will enact it. For instance, the proportional presence of women in politics was said to act as a powerful force helping address the underlying causes of their under-representation. (Tripp and Kang 2008; Dahlerup and Freidenvall 2010). Quotas could also allow political talent to be found equally from the pool of women and men (Murray 2014). A greater and more proportional presence of women in elected posts can have a profound impact on politics and society beyond the status of women. This can instigate an important shift from the political status quo, away from the traditional model of representation that favors elites and towards a more inclusive pattern of societal representation (Mansbridge 1999; Baltrunaite et al. 2012; Besley et al. 2012; Júlio and Tavares 2010; Murray 2013).

Campaigns for affirmative action and descriptive representation have pursued institutional change through the established formal constitutional norms without raising an objection to the fairness of the constitutional rules themselves. On the surface, this is a pragmatic stance in face of the existing constellation of institutions that are required to approve such a change of decision-making rules. More profoundly, however, this stance stands at odds with core arguments invoked to make the case for affirmative action according to which formal equality tends to reproduce undesirable social outcomes and is ipso facto unfair. The constitutional path to altering the decision-making rules presupposes that proponents of affirmative accept 'the view that in the last instance moral norms and values can only be justified by reference to the individuals concerned' (von der Pfordten 2012).

Nevertheless, constitutional change in conformity with normative individualism is a solution that remains normatively incompatible with a critique according to which formal equality tends to ignore and reproduce significant differences in social positions and capacities. The argument against formal equality is that oppression and inequality are inextricably linked to embedded social and political relations that construct disadvantaged groups (Young 1990, pp. 43-; Hayman 1992). It is by virtue of their social relations that multiple forms of domination and oppression emerge (Young 1989). This critique entails an explicit rejection of the formal process as flawed, on the grounds that it tends to 
disadvantage the voice and perspective of certain groups. Women have to battle against social barriers, prejudices and stereotypes (Dahlerup 2007; Escobar-Lemmon and TaylorRobinson 2009; Stevens 2012; Schneider and Bos 2014).1 Formal equality reflects embedded patterns of exclusion and marginalization. In that view, the fact that the numbers of women in elected offices significantly lag behind the share of women in the general population in almost all political constituencies is prima facie evidence of hidden barriers to entry affecting women as social and political actors, the result of their long-standing political exclusion, suppression and marginalization (Dahlerup 2002, p. 3; See also Baldez 2006; Dahlerup 2006; Krook and Childs 2006; Dahlerup 2007).

Invoking hidden barriers and stereotypes as causes of the systemic under-representation of women in elected positions launches a fundamental attack on formal political equality. From this perspective, quotas and other measures of affirmative action are necessary not merely because they will generate a desirable outcome - the proportional representation of women and other disadvantaged groups-but because they will correct intrinsic deficiencies of the decision-making process itself in view of stereotypes, biases and hidden barriers that affect preference formation and, consequently, input in decision making. This is a dependent interpretation of democracy; it invokes a judgment over which procedure is fair is that has been made with consideration of the kind of outcomes it is likely to produce. This stance circumvents the right of citizens to enact outcomes and select representatives in a way that simply mirrors their views - a range of views in which proponents of affirmative action discern several biases and prejudices. This co-dependent critique raises not just a question of fairness regarding social and political outcomes (to be remedied by changing the decision-making rules) but also poses a challenge to the legitimacy of any process governed by rules that do not remedy the bias they identify in society.

This fundamental critique of formal equality cannot consistently endorse a revision process that will follow this rule without making an important concession in terms of logical consistency. This critique must cover all institutional settings including the constitutional process. Quite interestingly, changing the decision-making rule by means of constitutional revision that conforms to formal equality - particularly by unanimity or supermajoritywill be an implicit acknowledgment that there may be no systemic bias in the first place, making their argumentation in favor of affirmative action redundant or exaggerated.

\section{Modifying the case for electoral quotas: the 'politics of presence' approach}

An important strand of thought in feminist theory puts forward a different argument in favor of electoral quotas: women have special perspectives that cannot be fully represented in politics by representatives of the opposite sex. These distinct perspectives stem from their separate identities and the experience of marginalization (Williams 1998, pp. 5-6). They cannot be completely understood and adopted by those who come from outside the group who experience them (Young 1989, p. 258). In this view, democracy should recognize and represent the distinct voices and perspectives of its constituent groups, 
including those of the oppressed and the disadvantaged (Cf. Young 1990, pp. 185-185; Young, 2000 p. 122). These group-specific perspectives must be expressed and advocated in decision-making posts by members of the demographic group who directly and personally experience them (Minow 1990, p. 286; Kymlicka 1995, pp. 138-139; See also Boyle 1983; Tremblay 1998; MacDougal 1998; Carroll 2001, Swers 2001; Campbell et al. 2010). The typical principal-agent relation will fail to take full account of this difference, especially in situations in which agendas are not previously configured and new problems and issues emerge; in those moments, 'who the representatives are' matters about what their choices will be (Phillips 1995, p. 44; See also Shapiro 1981; Young 1997; Williams 1998; Mansbridge 1999, 2005).

A comprehensive agenda for women's issues can be brought to politics by women themselves if they have a direct presence in all stages of decision-making (Phillips 1985, p. 176; See also Burnheim 1985. Dodson and Carroll 1991; Thomas 1994; Tamerius 1995; Vega and Firestone, 1995; Jones 1997; Reingold 2000; Carroll, 2001; Bratton and Ray 2002; Wolbrecht, 2002; Taylor-Robinson and Heath 2003; Bratton 2005; Swers 2005; Schwindt-Bayer 2006). Women will not just stand as women but they will also stand for women (See also: Childs 2006; Childs and Webb 2012; Celis et al. 2008). 'Presence' advocates the proportionate representation of group-level characteristics, such as gender, because descriptive representatives bring to the public sphere the perspective and life experience associated with their group and they will have a better capacity to advocate group-specific policy priorities (Phillips 1995, pp. 68 and 84. See also Diamond 1977; Brooks et al. 1990; Thomas 1994).

This approach both justifies and calls for the establishment of gender quotas in electoral processes so that both agenda-setting and discussions over policy-making should engage participants from across the societal divides and all needs and preoccupations should be properly articulated and heard (Phillips 1995, p. 53). In this view, representation is not limited to the representation of ideas, opinions and beliefs but it must acknowledge that the identity of policy-makers matters (See also Gould 1996, p. 184; Williams 1998). In this sense, fairness in decision-making entails an acknowledgment of the value of difference and the value of group-specific perspectives.

The need to secure the actual 'presence' of social groups in decision-making settings is articulated as an alternative to the typical concept of representation (Phillips 1995, pp. 4756). Phillips's 'politics of presence' modifies Young's critique of formal equality as failing to accommodate marginalized groups and Young's earlier advocacy of groupdifferentiated politics (Phillips 1995, pp. 47-56; See also Phillips 1998 and Young 1990). According to Phillips, formal equality alone distorts substantive representation by its very nature: Phillips states that equal presence matters for political inclusion:

... even if it proves to have no discernible consequences for the policies that may be adopted. Part of the purpose, that is, is simply to achieve the necessary inclusion; to reverse the previous histories of exclusion and the way these constituted certain kinds of people as less suited than the rest (1995, 40, emphasis added) 
As Phillips notes, the presence of the formerly excluded signals their political equality $(1995,40,45$.).2 This is a distinct vision of what fair political process is, in which the gender and any other social identity of the representative are politically significant and become an important part of what makes them representative (Phillips 1995, p. 13):

A decision-making chamber that acts for both sexes but is composed exclusively of one cannot be described as representative; nor can one that legislates for an ethnically diverse community but draws its representatives from only one group. Where the nature of representation is at issue, equality of outcome is not just a way of scrutinising the claims of equal opportunity. It becomes an important objective in itself. (Phillips, 2004, p. 9)

Drawing on a version of 'substantive representation', Phillips makes a clear statement that representative institutions governed by the principle of 'one person, one vote' must be complemented by the descriptive representation of certain groups whose distinct voice must be heard (See also Williams 1998). In that way, Phillips creates a synthesis: the descriptive representation of one group is justified on the grounds that any other process would prevent the full substantive representation of that group. 'Presence' is a necessary component of a 'revitalized' democracy as a constitutional commitment to diverse representation of groups whose perspective and issues will be otherwise overlooked (Phillips 1998, p. 228). By changing the balance between participation and representation, it offers a solution to the problem of representation with a notion of justice that concerns the appropriate process, not just the desirable outcome of representation (Phillips 1995, p. 63, 1998, p. 238).

This line of argument is compatible with a contractarian-constitutional view insofar as the decision-making process involves the whole population or a constitutional assembly in which the presence of women is proportionate to their percentage in the population. The proportional presence of women will legitimize the constitutional process. However, a constitutional decision that does not enact equal presence as the post-constitutional rule may be again vulnerable to criticism: decision makers have failed to grasp the fundamental value of equal presence for representation at all levels. This objection again reflects a 'dependent interpretation' of democracy in which choices over mechanisms and procedures must be made with consideration of the kind of outcomes they are likely to produce (Phillips 1995, p. 38).

Generally speaking, dependent interpretations of democracy turn a consequentialist argument about fairness in outcome into a normative argument about fairness in process, which is the benchmark for legitimizing political outputs. On the issue of fairness, one strand of arguments sees inherent flaws in formal equality and the typical, 'one vote, one person' representation (Young 1990) while another strand in the 'politics of presence' approach contends that a system of representation must combine descriptive and typical principal-agent elements (Phillips 1995). From this perspective, quotas and other measures of affirmative action are necessary not merely because they will generate a desirable 
outcome - the proportional representation of women and other disadvantaged groups - but also because they correct intrinsic deficiencies in the decision-making and representation process.

The strongest articulation of a 'dependent interpretation' is found in the critique in decision-making as intrinsically deficient in view of stereotypes, biases and hidden barriers. The 'politics of presence' approach can be read as a milder version of a dependent interpretation of democracy. Still, under different circumstances, this perspective articulates a more staunch critique of formal equality: imagine a situation in which the social causes of under-representation no longer exist; yet according to 'presence' the rules of representation will still be considered as flawed insofar the physical presence of women in politics is lagging far behind their share of the general population. This is because group identity matters per se, and the formal process remains intrinsically deficient if it fails to achieve equal presence even if one day the world moves to a state of affairs in which women fully enjoy the status and standards of treatment similar to men. In a hypothetical scenario of full equal social standing in social life between men and women, the proportionate presence of women must still be instituted at all times and at all levels. Quite significantly, this view of fairness cannot be legitimately rejected by a 'higher-level' constitutional process of decision making: such a post-constitutional rule will fall short of fairness in the first place.

\section{Final remarks}

This article points to the problem of constitutional legitimation, which stems from the presence of 'dependent' interpretations of decision-making rules in the constitutional process. Dependent views of procedural fairness propound an opinion on which decisionmaking rules are legitimate on the basis of what kind of outcomes they are likely to produce and, as a result, generate a clash of two irreconcilable visions of procedural fairness: on the one side, a constitutional-contractarian approach which endorses formal equality as the fundamental procedural rule of fairness, asserts its legitimacy on the basis of the equal worth of each individual person and claims that it is agnostic to the outcomes the decisionmaking process will generate, versus, on the other side, a dependent view of fairness that is found in arguments for affirmative action, which challenges this idea of procedural neutrality and puts forward two co-dependent proposals for institutional change: (1) grouplevel redistribution of rights and resources and (2) the amendment of the decision-making process itself to accomplish this redistribution. In promoting a vision of procedural fairness on the basis of an envisaged desired outcome, proponents of affirmative action put forward an entangled argument that launches a attack on both the outcomes and the processes governed by formal equality; the latter will generate undesired outcomes by disadvantaging the voice and perspective of certain groups and will reflect and institutionalize existing patterns of exclusion and marginalization.

While a constitutional-contractarian process can introduce a legitimate post-constitutional that departs from this principle, the presence of dependent interpretations of procedural 
legitimacy in this debate creates a paradoxical situation. Given the institutional status quo and the diversity of views on the subject, proponents of affirmative action must submit their proposals to the established decision-making process which they claim it is not impartial. If they get their desired outcome through the established decision-making rules, their underlying arguments may be ipso facto undermined. If they don't, their critique of procedural fairness allows them to challenge the decision-making process as intrinsically unfair.

In essence, dependent interpretations of procedural legitimacy constrain constitutional choice by placing a particular view of fairness above public deliberation. For a constitutional process to be universally accepted as legitimate all the parties involved have to consider its rules to be fair; this is only feasible if everyone acknowledges the equal normative worth of all competing views and seek to agree, on that basis, on a decisionmaking rule that unanimously reflects this acknowledgment. In the absence of prior consensus on these decision rules, the question of procedural legitimacy becomes an irresolvable problem for constitutional choice.

\section{References}

Bacchi, Carol Lee. (2006). Arguing for and against quotas: Theoretical issues. In Drude Dahlerup (Ed.), Women, quotas and politics. London/New York: Routledge, 32-51.

Baldez, Lisa. (2006). The Pros and cons of gender quota laws: What happens when you kick men out and let women in?. Politics \& Gender, 2, 102-109.

Baltrunaite, Audinga, Piero Bello, Alessandra Casarico, and Paola Profeta. (2012). Gender quotas and the quality of politicians. Mimeo, Bocconi University.

Bergmann, Barbara. (1996). In defense of affirmative action. New York: Basic Books.

Besley, Timothy, Olle Folke, Torsten Persson, and Johanna Rickne. (2012). Gender quotas and the crisis of the mediocre man. Mimeo, Centre for Economic Policy Research.

Boyle, Christine. (1983). Home-rule for women: power-sharing between men and women. Dalhousie Law Journal, 7, 790-809.

Boxill, Bernard. (1972). The morality of reparation. Social Theory and Practice, 2, 113123.

Boxill Bernard. (1984). Blacks and social justice, Rowman \& Littlefield, 1984.

Bratton, Kathleen A. (2005). Critical mass theory revisited: The behavior and success of token women in state legislatures. Politics and Gender, 1, 97-125

Bratton, Kathleen A., and Ray, Leonard P. (2002). Descriptive representation, policy outcomes, and municipal day care coverage in Norway. American Journal of Political Science, 46, 428-437.

Brooks, Rachel, Angela Eagle and Claire Short, C. (1990). Quotas now: Women and the Labour Party. London: Fabian Pamphlet. 
Buchanan, James M. and Gordon Tullock. (1962). The calculus of consent. Ann Arbor: University of Michigan Press.

Buchanan James M., and Roger D. Congleton (1998). Politics by principle, not interest: Toward nondiscriminatory democracy. Cambridge: Cambridge University Press, 1998.

Burnheim, John. (1985). Is democracy possible? The alternative to electoral politics. Cambridge: Polity/Blackwell.

Campbell, Rose, Sarah Childs and Joni Lovenduski. (2010). Do women need women representatives. British Journal of Political Science, 40, 171-194.

Carroll, Susan J. (2001). Representing women: women state legislators as agents of policyrelated change. In Susan J. Carroll (Ed.), The impact of women in public office. Bloomington and Indianapolis: Indiana University Press, 3-21.

Carter Stephen L. (1991). Reflections of an affirmative action baby. New York, NY: Basic Books.

Celis, Karen, Sarah Childs , Johanna Kantola, and Mona L. Krook. (2008). Rethinking women's substantive representation. Representation, 44, 99-110.

Childs, Sarah. (2006). The house turned upside down? the difference Labour's women MPs made. In Marian Sawer, Manon Tremblay and Linda Trimble (Eds.), Representing women in parliament (pp. 152-167). Oxford: Routledge.

Childs, Sarah., and Krook Mona Lena. (2006). Gender and politics: The state of the art. Politics, 26, 19-28.

Childs, Sarah, and Paul Webb. (2012). Sex, gender and the conservative party. Basingstoke: Palgrave.

Crenshaw Kimberlé. (1991). Mapping the margins: intersectionality, identity politics, and violence against women of colour. Stanford Law Review, 43, 1241-99.

Dahlerup, Drude. (2002), Using quotas to increase women's political representation. International IDEA, 2002, Women in Parliament, Stockholm.

Dahlerup, Drude. (2006). Introduction. In Drude Dahlerup (Ed.), Women, quotas and politics. New York: Routledge: 3-31.

Dahlerup, Drude. (2007). Electoral gender quotas: Between equality of opportunity and equality of result. Representation, 43, 73-92.

Dahlerup, Drude, and Lenita Freidenvall. (2005). Quotas as a 'fast track' to equal representation for women. International Feminist Journal of Politics, 7, 26-48.

Dahlerup, Drude and Lenita Freidenvall. (2010). Judging gender quotas: predictions and results. Policy and Politics, 38, 407-425.

Darcy, Robert, Welsh, Susan and Clark, Janet. (1994). Women, elections and representation. Lincoln NB: University of Nebraska.

Diamond, Irene. (1977). Sex roles in the State House. New Haven CT: Yale University Press.

Dodson, Debra, and Susan J. Carroll. (1991). Reshaping the agenda: Women in state legislatures. New Brunswick: Eagleton Institute of Politics. 
Dovi, Suzanne. (2002). Preferable Descriptive Representatives: Will just any woman, black, or latino do?. American Political Science Review, 96, 729-743.

Dworkin, Ronald. (1988). What is political equality?. University of San Francisco Law Review, 22, 1-30.

Escobar-Lemmon, Maria, and Michelle Taylor-Robinson. (2009). Getting to the top: career paths of women in Latin American cabinets. Political Research Quarterly, 62, 68599.

Fullinwider, Robert K. (1980). The reverse discrimination controversy. a moral and legal analysis. Woods Hall, University of Maryland: Institute for Philosophy and Public Policy.

Gay, Claudine. (2002). Spirals of trust? The effect of descriptive representation on the relationship between citizens and their government. American Journal of Political Science, 46, 717-733.

Gould, Carol. (1996). Diversity and democracy: Representing differences. In Seyla Benhabib (Ed.), Democracy and difference: Contesting the boundaries of the political (171-186). Princeton: Princeton University Press.

Guadagnini, Marila. (1998). The debate on women's quotas in Italian electoral legislation. Swiss Political Science Review, 4, 97-102.

Hayman, Robert L. Jr. (1991). Re-cognizing inequality: rebellion, redemption and the struggle for transcendence in the equal protection of the law. Harvard Civil Rights-Civil Liberties Law Review, 27: 48-49.

Htun, Mala. (2004). Is gender like ethnicity? The political representation of identity groups. Perspectives on Politics, 2, 439-58.

Jones, Mark P. (1997). Legislator gender and legislator policy priorities in the argentine chamber of deputies and the United States House of Representatives. Policy Studies Journal, 25, 613-629.

Júlio, Paolo, and José Tavares. (2010). the good, the bad and the different: Can gender quotas raise the quality of politicians?. Mimeo, Centre for Economic Policy Research.

Landau, Iddo. (1997). Are you entitled to affirmative action?. International Journal of Applied Philosophy, 11, 17-22.

Kennedy, Randall. (1986). "Persuasion and distrust: A comment on the affirmative action debate." Harvard Law Review, 99, 1327-1346.

Kymlicka, Will. (1993). Group representation in Canadian politics. In F. L. Seidle (Ed.), Equity and community: The charter, interest advocacy and representation (61-90). Toronto: IRPP.

Kymlicka, Will. (1995). Multicultural citizenship: A liberal theory of minority rights. Oxford: Oxford University Press.

Krook, Mona Lena. (2004). Gender quotas as a global phenomenon: Actors and strategies in quota adoption. European Political Science, 3, 59-65.

Lawrence III , Charles R. (2001). Two views of the river: A critique of the liberal defense of affirmative action. Columbia Law Review, 101, 928-976. 
Lovenduski, Joni. (1997). Gender politics: A breakthrough for women?. Parliamentary Affairs, 50, 708-19.

MacDougal, L. (1998). Westminster women. London: Vintage.

Mansbridge, Jane. (1999). Should blacks represent blacks and women represent women? A contingent "yes". The Journal of Politics, 61, 628-657.

Mansbridge, Jane. (2005). Quota problems: combating the dangers of essentialism. Politics \& Gender, 1, 622-38.

Maier, Charles S., and Klausen, Jytte. (Eds) (2001). Has liberalism failed women? assuring equal representation in Europe and the United States. New York: Palgrave.

Meadowcroft, John. (2014). Exchange, unanimity and consent: A defence of the public choice account of power. Public Choice, 158, 85-100.

Meier, Petra. (2000). The evidence of being present: guarantees of representation and the Belgian example. Acta Politica: International Journal of Political Science, 35, 64-85.

Minow, Martha. (1990). Making all the difference: inclusion, exclusion and American Law. Ithaca, NY: Cornell University Press.

Mosley, Albert G., and Nicholas Capaldi. (1996). Affirmative action; social justice or unfair preference?. Boston: Rowman and Littlefield, 1996.

Murrey, Rainbow. (2013). Quotas, citizens and norms of representation. Politics and Gender, 9, 304-309

Murrey, Rainbow. (2014). Quotas for men: Reframing gender quotas as a means of improving representation for all. American Political Science Review, 108, 520-532.

Nussbaum Martha. (1999). Sex and social justice. New York: Oxford University Press.

Phillips, Anne. (1991). Engendering democracy. Cambridge: Polity Press.

Phillips, Anne. (1995). The politics of presence. Oxford: Oxford University Press.

Phillips, Anne (1998). Democracy and representation: or, why should it matter who our representatives are. In Anne Phillips (Ed.), Feminism and politics (pp. 224-241). Oxford: Oxford University Press 1998).

Phillips, Anne (2004), Defending equality of outcome, Journal of Political Philosophy, 21, 1, pp. 1-19.

Reingold, Beth. (2000). Representing women: Sex, gender, and legislative behavior in Arizona and California. Chapel Hill : University of North Carolina Press.

Rhode, Deborah L. (1999). Speaking of sex: The denial of gender inequality. Cambridge MA: Harvard University Press.

Russell, Meg. (2000). Women's Representation in UK politics: What can be done with the law?. London: The Constitution Unit.

Sapiro, Virginia. (1981). When are interests interesting? The problem of political representation of women. American Political Science Review, 75, 701-716.

Sowell, Thomas, (2004). Affirmative action around the world: an empirical study. Yale University Press. 
Stevens, Anne. (2012). Comparing and assessing gender effects in political leadership. In Ludger Helms (Ed.) Comparative Political Leadership (pp207-226). Basingstoke: Palgrave.

Swers, Michelle. (2001). Understanding the policy impact of electing women: Evidence from research on Congress and State Legislatures. Political Science and Society, 34, $217-$ 220.

Swers, Michelle. (2005). Connecting descriptive and substantive representation: An analysis of sex differences in cosponsorship activity. Legislative Studies Quarterly, 30, 407-433.

Schneider, Monica. C. and Angela L. Bos. (2014). Measuring stereotypes of female politicians. Political Psychology, 35, 245-266.

Schwindt-Bayer, Leslie A. (2006). Still Supermadres? Gender and policy priorities of Latin American legislators. American Journal of Political Science, 50, 570-685.

Tamerius, Karin L. (1995). Sex, gender, and leadership in the representation of women. In Georgia Duerst-Lahti and Rita Mae Kelly (Eds.), Gender, power, leadership, and governance. Ann Arbor: University of Michigan Press, 93-112.

Taylor-Robinson, Michelle, and Heath, Roseanna Michelle. (2003). Do women legislators have different policy priorities than their male colleagues? A critical test. Women \& Politics, 24, 77-101.

Tebble, Adam. J. (2002). What is the politics of difference?. Political Theory, 30, 259-281.

Thomas, Sue. (1994). How women legislate. New York: Oxford University Press.

Thomas Sue and Welch Susan. (1991). The impact of gender on activities and priorities of state legislators. Western Political Quarterly, 44, 445-456.

Thomson, Judith Jarvis. (1977). Preferential hiring. In Marshall Cohen, Thomas Nagel and Thomas Scanlon (Eds.), Equality and preferential treatment. Princeton: Princeton University Press.

Tremblay, Manon. (1998). Do female MPs substantively represent women?. Canadian Journal of Political Science, 31, 435-65.

Tripp, Aili Mari and Alice Kang. (2008). The global impact of quotas: on the fast track to increased female representation. Comparative Political Studies, 41, 338-361.

Vanberg, Viktor J. (2004), The Status Quo in Contractarian Constitutionalist Perspective. Constitutional Political Economy 15, 153-170.

Vega, Arturo, and Firestone, Juanita M. (1995). The effects of gender on congressional behavior and the substantive representation of women. Legislative Studies Quarterly, 20, $213-222$.

von der Pfordten D. (2012). Five Elements of Normative Ethics - A General Theory of Normative Individualism. Ethical Theory and Moral Practice, 15, 4, 449-471.

Ward, R., Jones R., Hughes J., Humberstone N. and Pearson R. (2008). Intersections of ageing and sexuality: accounts from older people (pp. 45-72). In R. Ward and B. Bytheway 
(Eds.), Researching age and multiple discrimination. London: Centre for Policy on Ageing/The Open University.

Wängnerud, Lena. (2000). Testing the politics of presence: Women's representation in the Swedish Riksdag. Scandinavian Political Studies 23, 67-91.

Weldon, S. Laurel. (2002). Beyond bodies: Institutional sources of representation for women in democratic policymaking. Journal of Politics, 64, 1153-1174.

Williams, Melissa. (1998). Voice, trust and memory: marginalized groups and the failings of liberal representation. Princeton, NJ: Princeton University Press.

Wilson William J. (1987). The Truly disadvantaged: The inner city, the underclass, and public policy. Chicago: University of Chicago Press.

Wolbrecht, Christina. (2002). Female legislators and the women's rights agenda: from feminine mystique to feminist era. In Cindy Simon Rosenthal (Ed.), Women transforming Congress (pp. 170-197). University of Oklahoma Press.

Young Iris M. (1989). Polity and group difference: a critique of the ideal of universal citizenship. Ethics, 99, 250-274.

Young, Iris M. (1990). Justice and the politics of difference. Princeton: Princeton University Press.

Young, Iris M. (1993). Together in difference: transforming the logic of group political conflict. In Judith Squires (Ed.), Principled positions: postmodernism and the rediscovery of value (pp. 121-150). London: Lawrence and Wishart.

Young, Iris M. (1997). Deferring group representation. In Will Kymlicka and Ian Shapiro (Eds.), Nomos: Group rights. New York: New York University Press

Young Iris M. (2000). Inclusion and democracy. Oxford: Oxford University Press. 